Article

\title{
What Explains Change-Supporting Behavior within Local Agenda 21 Civil Society Groups to Promote Sustainable Development?
}

\author{
Christoph Zacher ${ }^{1}\left(\mathbb{D}\right.$, Marieke Born ${ }^{1}$, Stefan Wurster ${ }^{2, *} \mathbb{D}$ and Alexandra Michel ${ }^{1,3}$ \\ 1 Institute of Psychology, Heidelberg University, 69117 Heidelberg, Germany; zacher@gmx.de (C.Z.); \\ marieke.born@med.uni-heidelberg.de (M.B.); alexandra.michel@psychologie.uni-heidelberg.de (A.M.) \\ 2 TUM School of Social Sciences and Technology, Technical University Munich, 80333 Munich, Germany \\ 3 Federal Institute for Occupational Safety and Health, 44149 Dortmund, Germany \\ * Correspondence: stefan.wurster@hfp.tum.de
}

Citation: Zacher, C.; Born, M.; Wurster, S.; Michel, A. What Explains Change-Supporting Behavior within Local Agenda 21 Civil Society Groups to Promote Sustainable Development? Sustainability 2021, 13, 12476. https:// doi.org/10.3390/su132212476

Academic Editor:

Jennifer Martínez-Ferrero

Received: 5 October 2021

Accepted: 8 November 2021

Published: 11 November 2021

Publisher's Note: MDPI stays neutral with regard to jurisdictional claims in published maps and institutional affiliations.

Copyright: (c) 2021 by the authors. Licensee MDPI, Basel, Switzerland. This article is an open access article distributed under the terms and conditions of the Creative Commons Attribution (CC BY) license (https:// creativecommons.org/licenses/by/ $4.0 /)$.

\begin{abstract}
Civil society groups and their members are important agents within the multi-stakeholder change process towards more ecological, social, global, and economic sustainability. To better understand civil society group members' drivers within this complex societal change process, the present study examines the impact of perceived participation, leader-member exchange (LMX), procedural justice, and procedural justice climate on change-supporting behavior. Referring to social exchange theory, data from 125 members of 34 civil society groups that engage in the Agenda 21 process in Germany were gathered by paper/pencil and online questionnaires. Multi-level analyses were conducted to examine interactions between group-level and individual-level phenomena. We found that participation and LMX positively affected group members' procedural justice perceptions and that procedural justice positively affected group members' change-supporting behavior. Procedural justice further mediated the relationship between participation, LMX, and change-supporting behavior. The study's results suggest that fair social exchange processes with civil society group members should be more encouraged by other societal stakeholders (i.e., government, civil society group leaders) wishing to maximize civil society group members' change-supporting behavior. This study demonstrates ways to promote change initiatives in civil society. Fair social exchange processes help to overcome participation hurdles in the complex field of sustainable local development.
\end{abstract}

Keywords: sustainability; social change; procedural justice; civil society; agenda 21 process; leadership

\section{Introduction}

The 1992 United Nations Conference on Environment and Development held in Rio de Janeiro produced a comprehensive declaration known as Agenda 21. In 27 principles, the Rio declaration delivers a blueprint of measures to be taken globally, nationally, and locally to foster global sustainable development and societal change. Within this framework, special emphasis was given to the necessity of involving local change activists as experts of their communal environment [1]. Accordingly, the central idea and objective of Agenda 21 was to strengthen the cooperation between local grassroots initiatives, in the form of civil society groups or non-governmental organizations (NGOs), with regional governments or stakeholders in the economic sector. Civil society groups, according to the Organisation for Economic Co-operation and Development (OECD), are defined as follows:

"The multitude of associations around which society voluntarily organizes itself and which represent a wide range of interests and ties. These can include community-based organisations, indigenous peoples' organisations and non-government organisations."

[2] (p. 145)

The Agenda 21 policy aims for a more sustainable society and can be defined as a participatory and collaborative multi-stakeholder process, implemented at the local level 
and adapted to local challenges [1]. The term sustainability hereby refers to its ecological, social, and economic components [3]. In 1999, 90\% of German communities perceived it as their responsibility to fulfill the Agenda 21 action plan, and $68 \%$ had already established new partnerships with local civil society initiatives [4]. However, after the end of a booming period at the beginning of the 2000s, many German municipalities were no longer able to cope with the resource-consuming and complex task of the Agenda 21 process. While some collapsed because of declining political support, in most cases Agenda 21 processes fell asleep because of insufficient long-term engagement of civil society groups [5]. Even in cases where Agenda 21 was formally continued, frequently under a changed label, long-term involvement of civil groups played a decisive role for the sustainability success and in-depth change of a municipality [6]. Considering the core idea of Agenda 21 and witnessing the current ambivalent situation of its implementation in German municipalities, the question arises: What factors help or hinder local Agenda 21 group members, such as civil society group members or NGOs' employees, in continuing Agenda 21 processes in German municipalities promoting societal change towards more sustainability?

To answer these questions and better understand civil society group members' drivers within this societal change process towards more sustainability, in our study we examine the impact of perceived participation, leader-member exchange (LMX), procedural justice, and procedural justice climate on civil society group members' change-supporting behavior (see Figure 1). Thereby, we draw on the theoretical assumptions of social exchange theory $[7,8]$.

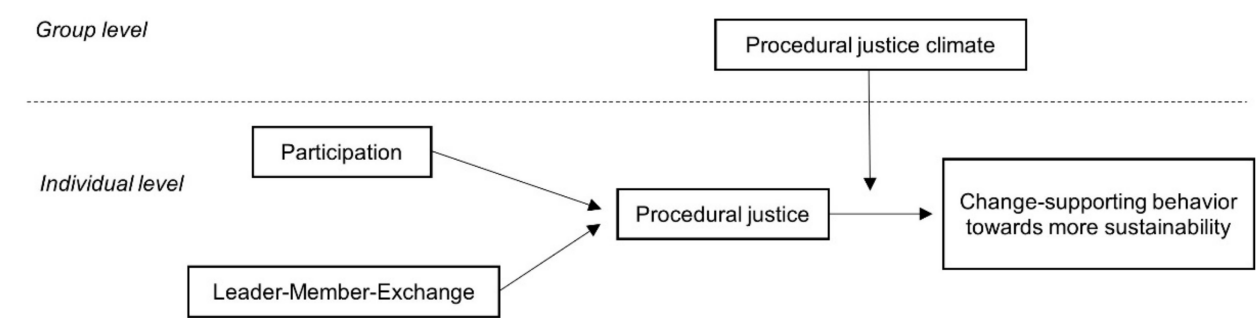

Figure 1. The proposed conceptual scheme.

This study contributes to the literature in the following way. Although social exchange theory has been used to explain employees' change-supporting behavior during organizational change $[9,10]$, based on this theory the impact of perceived participation, LMX, and procedural justice has less frequently been examined in the context of societal change towards more sustainability [11]. By applying social exchange theory $[7,8]$ within a societal change context, we transfer this theory to this area of research. Thus, we offer practical implications for members of grassroots initiatives or NGOs and other stakeholders within municipalities aiming for a more sustainable society.

We proceed as follows: After giving an overview on the state of research regarding local Agenda 21 processes, we provide in this first section our conceptual framework, based on different theories on the individual and group level. The hypotheses derived from this are empirically tested in Section 3. Section 2 describes our method and data. In Section 4, we discuss the results, describe their theoretical and practical implications, and provide a research outlook.

\subsection{Status Quo of Agenda 21 Research - What Is Missing?}

To examine success factors within the Agenda 21 context, most scientific research so far has focused on the macro level of this societal change process and mainly contributed to fostering an understanding of certain structural factors that lead to a successful local Agenda 21 implementation $[3,4,6,12]$. In this light, comparative case studies have indicated that the level of governmental institutionalization of the Agenda 21 process is one of the main factors for effective Agenda 21 implementation and regional sustainable development. One often-cited characteristic of successful communities is the establishment of Agenda 21 offices in local senate departments $[4,12]$. While such professionalized and 
politically anchored structures may be of high value in this societal change process towards sustainability, establishing a participatory and collaborative relationship between different change agents, as proposed by the Agenda 21 action plan, does not stop here. Especially for civil groups and initiatives that form the backbone of every local Agenda 21 process and are essentially based on voluntary members, mechanisms that promote intrinsic motivation are of central importance-this against the background that the goals of a local Agenda 21 process are not (only) self-centered, since taking over long-term responsibility for the interests of future generations are at its center. It should be noted that local Agenda 21 groups cover a wide range of interests and initiatives. They range from national environmental associations, local sustainability groups, and social associations, to political initiatives. Wolf [3] notes that informal structures, which can result from individual needs, interests, or abilities, have the power to alter or even overrule such formal structures. Differences in action patterns, interests, power, resources, or even organizational cultures between different societal stakeholders may bear possible conflicts that could ultimately prevent the Agenda 21 process from succeeding [12]. Underscoring this assumption, Brand, Christ, Heimerl, Rau, and Warsewa [13] describe social change towards more sustainability as the result of an interactive learning process that is based on reciprocal communication and entails the exchange and reflection of experiences between change agents. Referring to social exchange theory $[7,14]$, local agenda processes including different stakeholders (civil groups and their members) can be characterized as transaction forums. In the context of societal change, it can be assumed that members of different local Agenda 21 groups who feel involved in local Agenda 21 processes and experience high-quality communication with group leaders or group representatives/speakers are more likely to perceive decision-making processes as fair. Procedural justice signals to local Agenda 21 group members that their engagement, work, and knowledge are honored and that they are respected members of the group and significant promoters of the local Agenda 21 change process. In return, group members should promote the change within municipalities towards more sustainability with their own change-supporting behavior. As a result, they may significantly contribute to the local change processes. Although one can assume that sustainable development requires cooperation and exchange between different local Agenda 21 groups and other stakeholders throughout the local change process, to our knowledge, no study in the field of societal change has specifically examined social exchange relationships within the local Agenda 21 process. This is surprising, as social exchange relationships in other multi-stakeholder change contexts have been studied in the past and have yielded important results. From the field of organizational change management research, we know that social exchange relationships between employees and other organizational stakeholders influence employees' attitudes and behaviors during change [15-17]. We argue that findings from organizational change management research can be of high relevance for local Agenda 21 change processes, too. Thus, building on social exchange theory $[7,8]$, we seek to contribute to this gap in change management research by focusing on local Agenda 21 group members and their perceptions of the social exchange processes within the local Agenda 21 change process. Specifically, we aim to examine determinants (i.e., participation and leader-member exchange) of change-supporting behavior towards sustainable development within a municipality.

\subsection{Local Agenda 21 Change: The Role of Social Exchange}

For successful change processes in traditional organizations, various stakeholders across functions and hierarchy need to be aligned with an ongoing change. In societal change towards sustainable development within a municipality, relevant stakeholders include political decision makers, governmental administrations and companies, and citizens organized in local Agenda 21 groups. Wolf [3] argues that from a sociological perspective, the interaction and social exchange processes between different stakeholders within the local Agenda 21 process are to a high degree comparable to exchange processes within traditional forms of organizations. This assumption builds on the observation that both 
entities constitute social systems with communication, cooperation, and coordination processes that focus on organizing problems of cooperation and coordination. Furthermore, both local Agenda 21 processes within municipalities and organizational change processes focus on long-term impact and comprise similar structural components, such as goals, social structure, stakeholders, and the environment. According to de Haan, Kuckartz, and Rheingans [18], this comparison holds especially true when comparing Agenda 21 processes to non-profit organizations as both forms serve a public or political purpose rather than generating profit. Assuming that both societal and organizational change processes are structurally comparable, it is reasonable to draw on the theories and findings of organizational change management research to explore social exchange processes and their impact within the Agenda 21 setting more thoroughly. As an overarching theoretical framework, the present study draws on social exchange theory $[7,8]$. Social exchange theory generally argues that humans engage in social transactions. These social transactions are based on the norm of reciprocity [14] and, in contrast to economic exchanges, contain socioemotional goods, such as support, loyalty, respect, or approval. The theory argues that people are motivated by self-interest and actively seek social transactions that minimize costs and maximize benefits. Moreover, social transactions and exchanges go beyond person-to-person interactions, as it has previously been shown that individuals often think of whole organizations as possessing human-like qualities $[19,20]$. This means that individuals can engage in two-way transactions with whole social entities. Accordingly, if members of local Agenda 21 groups see that their group has participation possibilities within the local Agenda 21 process and may experience high-quality interactions with their group leaders or speakers, this should lead to the perception of just procedures (i.e., fair decision-making processes). In return, group members are likely to show change-supporting behavior in favor of more sustainability and will fairly discharge their obligations in the long run [21,22]. Thus, we first seek to evaluate in our study if local Agenda 21 group members who feel involved in the local change process (i.e., participation) and experience high-quality interaction (i.e., leader-member exchange) are likely to perceive procedures as just (i.e., procedural justice). Second, we aim to evaluate if the perception of procedural justice will in turn promote change-supporting behavior. Considering the diversity and interdependency of change agents in the Agenda 21 process, achieving such a positive dynamic between stakeholders should be highly desired to drive the change towards sustainable development successfully.

\subsection{The Role of Procedural Justice}

In the context of organizational change management, procedural justice has been identified as a key variable influencing employees' attitudes and behaviors [23]. According to Colquitt [24], procedural justice is one of four dimensions that constitute organizational justice, together with interpersonal justice, informational justice, and distributive justice. In this study, we focus on procedural justice because this is a pivotal determinant of social exchange processes' quality. Procedural justice is defined as the perceived fairness of decision-making processes [25,26]. Thibaut and Walker [27] found that procedures are perceived as fair when (1) people are able to voice their views and arguments during a procedure or (2) when they are able to influence the outcome of a procedure. Leventhal [25] expanded the concept of procedural justice to all sorts of social systems and added to Thibaut's and Walker's findings by defining six characteristics of procedural justice. Following Levethal's conceptualization, procedures of the local Agenda 21 process should be perceived as fair when they are (1) consistent (e.g., procedures of Agenda 21 are applied consistently across people/groups and time), (2) free of bias (e.g., governmental decision makers/group leaders are neutral), (3) based on accurate information (e.g., procedures of Agenda 21 are based on accurate information), (4) correctable (e.g., appeal procedures exist for correcting bad outcomes in the Agenda 21 procedures), (5) representative (e.g., all subgroups of the population affected by the decision during procedures of Agenda 21 are heard from), and (6) ethically acceptable (e.g., procedures of Agenda 21 uphold personal 
ethical and moral standards). Research has shown that procedural justice characteristics are positively related with change-supporting behavior [28], job satisfaction [29,30], and commitment to change [28]. Furthermore, the perceived fairness of change procedures has been identified as an important variable mediating the effects of certain process characteristics (e.g., participation, information, justification) on favorable organizational change outcomes [23,31]. These findings can be explained by social exchange theory, as desired procedural characteristics, shaped through interaction with the respective exchange partners, should motivate people to reciprocate favorable attitudes or behaviors $[7,8]$.

\subsection{Participation and Procedural Justice}

According to social exchange theory, in social exchanges, the norm of reciprocity can serve as a standard when evaluating the overall justice of an exchange relationship [32]. This means that agents in social exchange processes expect congruence between their investments and benefits when evaluating the fairness of the overall exchange processes. Having a say in shaping the change process and experiencing fair decision-making processes might present an adequate benefit to sustain a subjectively just exchange relationship. Several studies demonstrate that one's perceived opportunity to participate in decision-making procedures fosters the perception of procedural justice [33,34]. Paterson and Cary [35] showed that procedural characteristics, such as the ability to express one's views about the change process, increases employees' perceptions of fairness during a downsizing procedure. A study conducted with a sample of Canadian governmental employees that were exposed to a broad array of changes, such as administrative changes, showed similar effects of employee voice on perceived procedural justice [36]. In the context of the present study, one can infer that local Agenda 21 group members highly invest in the goal of sustainable development by demonstrating voluntary engagement, often in their spare time. Thus, participating in the local Agenda 21 change process by contributing to the definition of change objectives, being involved in decision-making processes within the municipality, and supporting the implementation of concrete changes within the municipality should positively influence group members' procedural justice perceptions, as this could be seen as a desired and fair return of investment. Based on this, we hypothesize the following:

Hypothesis 1 (H1). For civil society group members, the perceived ability of one's group to participate in local Agenda 21 change processes positively predicts individuals' perceived procedural justice.

\subsection{Leader-Member Exchange and Procedural Justice}

Drawing on social exchange theory, leader-member exchange (LMX) [37] (i.e., the relationship between a group leader and its members) can be described as a unique form of social exchange relationship that varies in quality between the respective agents of interaction [38-41]. In high-quality LMX relationships, leaders and members form social relationships based on trust, liking, and respect, which engenders feelings of mutual obligation and reciprocity [14,42]. In contrast, low-quality LMX relationships are characterized as not going beyond the basic, formally agreed on economic exchange, such as pay for performance. LMX has been shown to influence team members' work-related attitudes and behaviors in the traditional business sector as well as in non-profit organizations [43-45]. Exploring LMX within the boards of Australian voluntary sports organizations, Hoye [44] found high-quality LMX between board members and board executives, as well as board members and board chairs, to be significantly related to overall board performance. More specifically addressing the relationship between LMX and procedural justice, Bhal and Ansari [46] found that high-quality exchanges between leaders and members lead to on-thejob and off-the-job mechanisms of having a say, which in turn lead to members' perception of procedural justice. Dulebohn et al.'s [43] meta-analysis of antecedents and consequences of LMX provides additional support for the assumption that LMX influences procedural justice judgments, as they report a medium effect size for this relationship. In line with 
social exchange theory, local Agenda 21 group members engaging in high-quality relationships with their group leader or group speakers/representatives might do so because it enables them to better influence the group's overall decisions within the Agenda 21 process. Presumably, civil group members with a strong and emotional connection with the leader are more likely to be heard. In this sense, experiencing high-quality LMX should present an ideal condition for local Agenda 21 group members to ask questions and clarify uncertainties, and by that, to shape procedural fairness characteristics. This should again help to maximize one's benefit within this social exchange process. Thus, based on social exchange theory, we hypothesize the following:

Hypothesis 2 (H2). Leader-member exchange quality in civil society groups predicts members' perceived procedural justice insofar as high-quality LMX leads to more procedural justice.

\subsection{Procedural Justice and Change-Supporting Behavior}

Change-supporting behavior can be defined as behavior that is consistent with the goals of the change effort and therefore contributes to a planned change initiative $[16,28]$. Such behavior varies in the level of activity and can thus be placed on a continuum. In its most active form, change-supporting behavior is characterized by supporters demonstrating extreme enthusiasm for a change (i.e., championing the change) and by going beyond what is formally required to promote the change to others [28,47]. Local Agenda 21 group members mostly engage voluntarily in local change initiatives because they believe in the aims of the change and want to make society more sustainable. If group members support the change and even show championing behavior, it is likely that these actions will lead to greater dissemination of the group's intentions towards all societal stakeholders in the change process. At the same time, exerting change-supporting behavior should, according to social exchange theory, yield profitable attitudes and behaviors from other societal stakeholders in return [8]. Therefore, in order to reach the goal of sustainable development, it is of pivotal interest to examine how change-supporting behavior in civil society group members can be maximized. Social exchange theory posits that members who feel they are being treated fairly by their organization or leader are more inclined to exert behaviors that go beyond what is formally agreed on. Thus, according to Organ [48,49], the possibility for employees to develop long-term, social exchange relationships with employers provides a motive for performing extra-role behaviors at the workplace. Based on the norm of reciprocity, employees that are being treated fairly are prompted to reciprocate by demonstrating extra efforts. A body of empirical research supports the relationship between procedural justice and extra-role behaviors at the workplace [50-52]. In this regard, a meta-analysis exploring 25 years of procedural justice research indicates that procedural justice is a key variable in explaining workplace performance and organizational citizenship behavior [53]. Based on these findings and drawing on social exchange theory, we argue that the same mechanism might also work for employees and volunteer members in Agenda 21 groups and hypothesize the following:

Hypothesis 3 (H3). Procedural justice within the Agenda 21 process predicts change-supporting behavior towards sustainability insofar as civil society group members who perceive higher procedural justice will exert more change-supporting behavior towards sustainability.

\subsection{The Mediating Role of Procedural Justice}

Supposing that perceived participation opportunities and LMX lead to procedural justice and that procedural justice in turn leads to change-supporting behavior towards more sustainability, it is reasonable to propose that procedural justice may mediate the effects of participation and LMX on change-supporting behavior. Kernan and Hanges [23] found that in a company's reorganization process, procedural justice mediated the effects of employee participation on organizational commitment, job satisfaction, turnover intentions, and management trust. To our knowledge, there is no study that has examined the impact of 
LMX on change-supporting behavior via procedural justice. However, Bhal [54] found that procedural justice mediates the relationship between LMX and organizational citizenship behavior. Thus, in accordance with social exchange theory, we propose the following:

Hypothesis 4 (H4). Procedural justice mediates the positive relationship between the perceived ability of one's group to participate in local Agenda 21 change process and change-supporting behaviors towards sustainability.

Hypothesis 5 (H5). Procedural justice mediates the positive relationship between individually perceived LMX quality and change-supporting behaviors towards sustainability.

\subsection{Procedural Justice Climate}

Since the beginning of this century, research on procedural justice has evolved. Being seen as an individual-level fairness judgment at first, recent findings imply that procedural justice can also be conceptualized as a context variable affecting employee and work group behaviors and attitudes [55]. This group-level phenomenon, which describes a distinct and shared group-level cognition about how fairly a group as a whole is treated, goes by the term procedural justice climate [56]. Procedural justice climate has been shown to explain variance in workplace attitudes and behaviors beyond individual perceptions of procedural justice [57,58]. In this regard, Naumann and Bennett [56] found that procedural justice climate predicts individual-level helping behaviors in bank employees, even after controlling for individual-level procedural justice perceptions. Given the evidence that individuals form procedural justice perceptions based on their own perception of the justice aspects of decision-making processes, as well as based on other group members' perceptions, this possible group-level influence needs to be considered in the present study. Accordingly, members of local agenda groups might not solely draw justice-relevant information from their direct interaction with their group leader or speaker/representative, but also from observing how fellow group members are being treated. In line with social exchange theory, individuals reciprocate socioemotional attitudes and behaviors when they perceive the exchange relationship as fair and consistent $[7,8]$. Observing how fellow group members perceive procedural justice aspects should provide a unique cue in evaluating the overall perception of the exchange relationship's fairness and consistency. Consequently, this should impact group members' level of reciprocity. Following this line of reasoning, we propose that the groups' procedural justice climate influences civil society group members' change-supporting behavior when controlling for individual-level procedural justice. Thus, we hypothesize the following:

Hypothesis 6 (H6). Group-level procedural justice climate predicts change-supporting behavior towards sustainability in civil society group members after controlling for individual procedural justice perceptions.

Furthermore, due to the joint influence of personal and collective justice perceptions, one can infer that people might be most effectively prompted in exerting change-supporting behavior when both individual and group-level indicators point towards justice. Discrepancies, in turn, should provoke people to recalibrate their overall fairness judgment. Such an amplification effect could be shown by Shin et al. [58], who found a cross-level moderation effect of procedural justice climate on the relationship between procedural justice and helping behavior using a sample of employees of a large electronics company in Korea. This effect is in line with social exchange theory, as people who perceive the exchange process as fair will reciprocate by demonstrating behavior that goes beyond formal agreements [49]. Witnessing that one's peers perceive decision-making processes as fair should promote individuals' justice perceptions. In contrast, individuals who personally feel they are being treated fairly but at the same time witness unfairness perceived by others might question the overall reciprocity character of the exchange relationship and as a result reduce their activity level of change-supporting behavior. Therefore, we hypothesize: 
Hypothesis 7 (H7). Procedural justice climate moderates the effects of procedural justice perceptions on change-supporting behaviors, such that these effects are stronger when the procedural justice climate level is high than when it is low.

\section{Materials and Methods}

\subsection{Participants and Procedure}

The present study was conducted with German civil society groups that engage in Agenda 21 processes promoting ecological sustainability, social sustainability, or global justice topics in four German cities (Heidelberg, Mannheim, Pforzheim, and Stuttgart) located in the federal state of Baden-Württemberg, in the south of Germany, representing different framework conditions for local Agenda 21 processes. The selection of cases, including different local Agenda 21 groups in cities of different sizes and economic strengths, allows generalization for local Agenda 21 processes in different local contexts. In addition to pragmatic research considerations, the study was carried out in Germany since, on the one hand, a large number of local Agenda 21 processes were started here. On the other hand, difficulties in the implementation of local Agenda 21 processes also became apparent very quickly, since at the beginning of the 2000s a lot of them declined [59], raising the questions of why this happened and how to prevent it. In the four municipalities focused on, we find at least a rudimentarily functioning Local Agenda 21 process in place, even if it is not always officially named that way. The groups examined in this study range from environmental initiatives (e.g., food sharing, nature conservation, etc.) to tenants' or civic associations.

The participants of our survey received a survey package consisting of the main questionnaire, instruction sheets, and self-addressed return envelopes. The survey package was distributed to group members by a representative of the group or mailed directly to group members if previously agreed upon with the involved contacts. Optionally, an identical online questionnaire was provided and distributed. In exchange for their participation, groups were offered feedback about the study results as well as practical implications. Individual anonymity was hereby ensured.

Overall, the research team approached 116 disseminators. From these 116 disseminators, 61 disseminators could be reached and 56 offered to support the distribution of the questionnaire. Following the support of these contacts, 304 survey packages were mailed to members of 29 civil society groups. Additionally, we shared the online questionnaire with members of 27 groups in total. Responses were collected from 113 members of 28 groups via the survey package (response rate of $37.2 \%$ ) and 16 members of 6 groups from the online version.

Three participants were excluded from the analysis retrospectively because it was not possible to determine which group they belonged to, and one additional participant was excluded because it was not possible to calculate scale means due to missing data. As a result, the final sample included 125 civil society group members of 34 civil society groups (see Figure 2). Out of the 34 groups in this sample, 20 groups engaged in ecological sustainability (e.g., upcycling workshops, eco-mobility), 8 groups in social sustainability (e.g., reemployment programs, language courses for refugees), and 6 groups in fostering global justice (e.g., fair trade partnerships). The mean group size was $46(\mathrm{SD}=97.99)$ with a median of 15 group members. The sample consisted of $47.6 \%$ male and $52.4 \%$ female activists ranging in age from 17 to 80 years $(M=48.2, S D=15.8)$. Fifty-eight per cent of the participating activists had a university degree, an additional $10.6 \%$ had a doctorate degree, and $12.2 \%$ had completed an apprenticeship. The participants' mean tenure within their civil society group was 8 years ( $\mathrm{SD}=9.74)$, and the mean engagement was 8 working-hours per week $(S D=9.23)$. Ninety-seven per cent of the groups in the sample reported that their projects are mainly being initiated by themselves or that their projects are to the same extent being initiated by their regional government. No group reported that their projects were exclusively initiated by their regional government. 


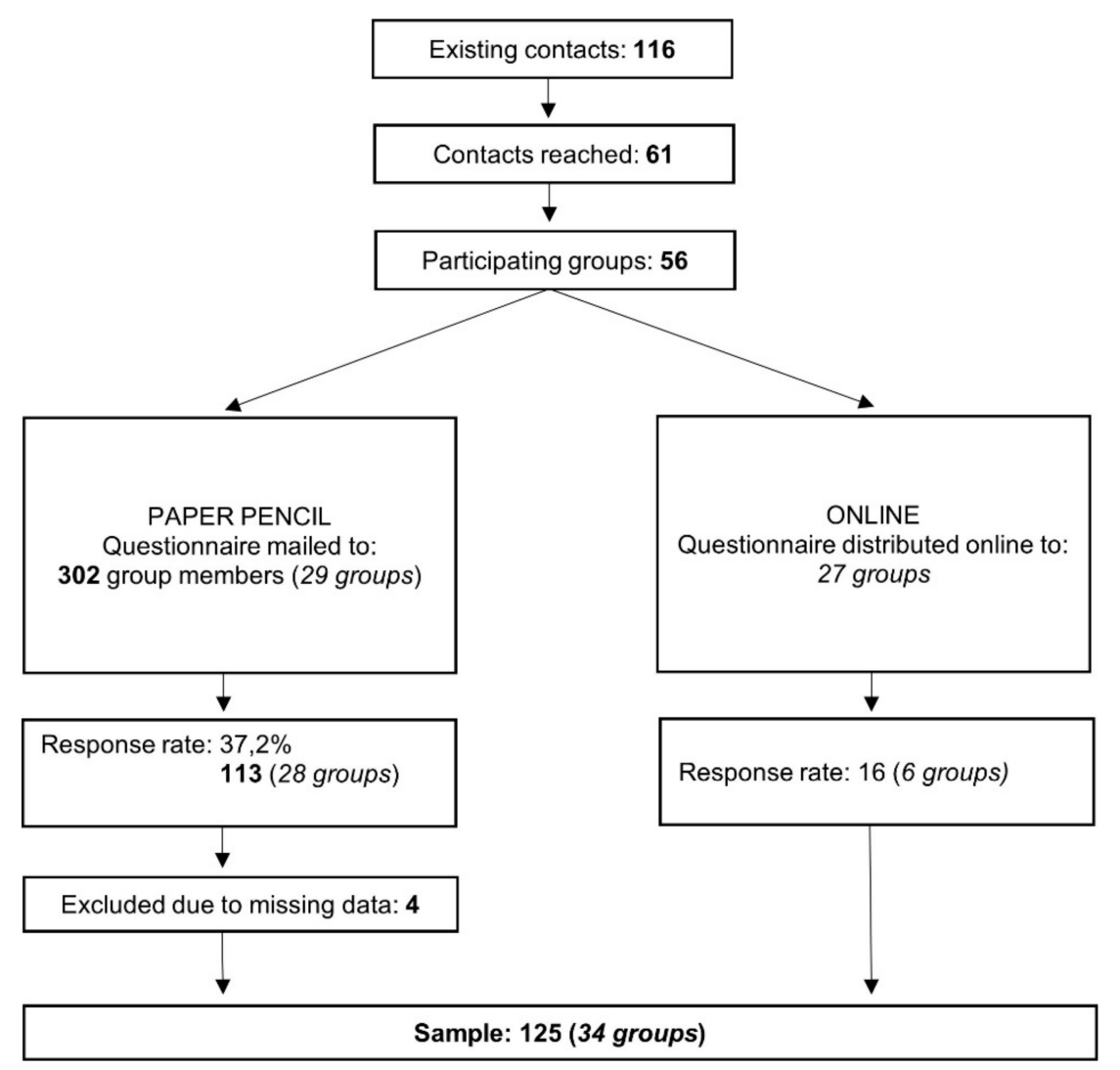

Figure 2. Sample acquisition.

\subsection{Measures}

For the present study, scales from the organizational change management literature were adapted to the context of the local Agenda 21 change process. To test the validity of these modifications, we conducted a plausibility check with an experienced Agenda 21 activist before finalizing the questionnaire. All items were assessed using a seven-point Likert-type scale, ranging from 1 (strongly disagree) to 7 (strongly agree).

Participation. To assess the individually perceived level of participation of one's local Agenda 21 group in its municipality, three items from the participation scale of Wanberg and Banas [30] were adapted to the study context. Wanberg and Banas's scale measures the individually perceived opportunity to participate in the context of change. The scale was available in German from a study conducted by Michel et al. [31]. The items read, "In our municipality, our group has been able to participate in the implementation of the changes that have been proposed and that are occurring", "In our municipality, our group has some control over the changes that have been proposed and that are occurring", and "If wanted to, our group could have had input into the decisions being made about the future of our municipality". The Cronbach's alpha of this scale was 0.72 .

Leader-Member exchange. We measured LMX quality using three items from a validated German version of Graen and Uhl-Bien's [37] seven-item LMX scale [60]. Items are "I would characterize my working relationship with my group leader as very effective", "The leader of my group would use his/her power to help me solve problems in my work in these projects", and "I have enough confidence in my group leader that I would defend and justify his/her decision". Cronbach's alpha for this scale was 0.83 .

Procedural justice. Procedural Justice was assessed using a validated German version of Colquitt's [24] scale by Maier, Streicher, Jonas, and Woschée [61] which was adapted to the study context. The scale consists of seven items. The items are "I am able to express my views and feelings about the sustainability projects' procedures", "I had influence over the assessments made as a result of the sustainability projects' procedures", The procedures 
used in the sustainability projects have been applied consistently", "The procedures used in the sustainability projects are based on accurate information", "I am able to appeal the assessments made by procedures used in the sustainability projects", "The procedures used in the sustainability have been free of bias", and "Those procedures of projects of sustainability have upheld ethical and moral standards". Cronbach's alpha was 0.74 .

Procedural justice climate. The individually perceived procedural justice perceptions of team members were aggregated at the team level using individual group members' mean scores to represent procedural justice climate levels. This method is known as the direct-consensus composition approach [62] and has been utilized by numerous justice climate researchers in the past $[57,63,64]$.

Change-supporting behavior towards more sustainability. Change-supporting behavior was measured using six items of Orth's [28] change support scale. The scale is comprised of three items measuring passive supporting behaviors and three items measuring active supporting behaviors. Items measuring passive supporting behaviors are "I tried to keep myself informed about this change towards more sustainability", "I spoke positively about this change towards more sustainability to others", and "I actively participated in meetings regarding this change towards more sustainability". Items measuring active supporting behaviors are "I worked consistently toward making this change towards more sustainability successful", "I encouraged others to support this change towards more sustainability", and "I tried to explain the benefits of this change to others towards more sustainability". Brislin's [65] back-translation method was applied to translate the scales into German. The measured Cronbach's alpha was 0.85.

Control variables. Furthermore, the demographic variables of gender, age, education, team size, group status (paid vs. voluntary work), and organizational tenure were assessed as control variables. Previous studies that examined behavioral reactions in organizations indicated that these variables could potentially confound the supposed hypotheses in this study [66].

\subsection{Analytical Approach}

Individual Agenda 21 activists in the sample were nested in civil society groups. To account for individual as well as possible group-level influences, hierarchical linear modelling (HLM), using the program HLM 7, was applied [67].

For the main analysis, a null model that included the intercept as the only predictor of change-supporting behavior was calculated. In Model 1, the first predictor of interest was included, and in Model 2, the hypothesized mediating variable was included. In Model 3 , the group-level predictor was entered, and in Model 4, the model was concluded by allowing cross-level interactions between the hypothesized variables. The improvement of each model over the previous model was tested by computing the difference scores of the respective likelihood statistics and submitting the difference to a $\chi^{2}$ test.

Considering the approach of Urban and Mayerl [68], to test the mediation hypotheses, the present study aimed to satisfy four requirements for mediated relationships. First, the independent variables should be significantly associated with the mediator. Second, the mediator variable should be significantly related to the dependent variable after controlling for the independent variables. Third, the indirect effect should be significant. Fourth, the effect of the first predictor on the outcome variable must decrease after the second predictor is added to the model. According to the authors, the fourth requirement is important, as it is possible to have a significant indirect effect but at the same time no mediation effect. In order to test the mediated relationships in the model proposed here, the relationships between participation and procedural justice as well as LMX and procedural justice were estimated. Then, after controlling for participation and LMX, respectively, the relationship between procedural justice and change-supporting behavior was estimated. Next, the indirect effects were calculated and tested for significance using the Sobel test [69]. Furthermore, whether the effects of participation and LMX on change-supporting behavior decreased after adding procedural justice to the models was tested. 
Before testing the proposed hypotheses, we needed to be ensure that hierarchical linear modeling in the data was justified. To do so, the between-group and within-group variance components of the outcome variable were examined to find out how much variance of the outcome variable can be explained by the variance that occurs between civil society groups. The ICC(1) for change-supporting behavior was $0.08, p=\mathrm{ns}$. According to the literature on multi-level modeling, this can be considered a small to medium effect, which indicates that the group level should be considered in the data analysis [70-72]. Hayes [70] argues that there are benefits for using multi-level modeling even when ICCs are near zero. Taking this into account, we found it justified to apply hierarchical linear modeling in the analysis notwithstanding that the estimation of variance components showed a non-significant group-level influence on change-supporting behavior.

The validity of the team-level aggregation of group member ratings of procedural justice was examined by evaluating within-team agreement $($ mean $\operatorname{rwg}(j)=0.69$; median $\operatorname{rwg}(j)=0.74)$. While these $\operatorname{rwg}(j)$ values were close the conventionally acceptable value of 0.70 , it should be noted that they were estimated using uniform null distribution and therefore potentially overestimate within-group agreement in the case of response bias [73,74]. Following the suggestions of Bliese [75], additional evidence regarding the validity of group-level constructs was collected by computing intra-class correlations (ICC $(1)=0.06$ and $\operatorname{ICC}(2)=0.18)$. ICC(1) represents the proportion of total variance that can be explained by group membership. ICC(2) represents an estimate of the reliability of the group means. The reported ICC values of procedural justice were lower than the desired values reported by Kirkman, Chen, Farh, Chen, and Lowe [76]. However, an ICC(1) of 0.06 can be considered a small effect according to other authors [70-72]. Moreover, according to Bliese [77], ICC(2) values are a function of ICC(1) values and group size. In the present study, the average number of participants per civil society group was only 3.7 (median $=3$ ), which may have resulted in a less reliable mean. Taking this into account, overall, we found it justified to create a team-level measure of procedural justice climate.

\section{Results}

Means, standard deviations, and correlations of all study variables are included in Table 1. Below the diagonal, correlation coefficients relating to individual-level variables (Level 1) are reported. Above the diagonal, correlation coefficients relating to group level variables (Level 2) are reported. Overall, the average age of group members in the sample was $48.19(S D=15.18)$ years with an average but firmly varying group tenure of $8.15(S D=9.74)$ years. To the greatest extent the questioned group members were voluntary workers from educational backgrounds that either qualify for higher education or have attended higher education. As one could expected from voluntary members of civil society groups that act in matters of sustainability the means of our test variables participation and change-supporting behavior tend towards high individual engagement at baseline.

Table 1. Means, standard deviations, and intercorrelations between study variables.

\begin{tabular}{|c|c|c|c|c|c|c|c|c|c|c|c|c|}
\hline Variable & $M$ & $S D$ & 1 & 2 & 3 & 4 & 5 & 6 & 7 & 8 & 9 & 10 \\
\hline$M$ & & & & & 5.06 & & & & & & & 35.50 \\
\hline$S D$ & & & & & 0.69 & & & & & & & 54.76 \\
\hline 1. Participation & 4.48 & 1.34 & & & & & & & & & & \\
\hline 2. LMX & 5.79 & 1.02 & 0.16 & & & & & & & & & \\
\hline 3. Procedural justice & 5.00 & 0.85 & $0.25 * *$ & $0.69 * *$ & & & & & & & & -0.14 \\
\hline 4.Change-supporting behavior & 5.63 & 0.94 & $0.28 * *$ & $0.55^{* *}$ & $0.70 * *$ & & & & & & & \\
\hline 5. Gender ${ }^{1}$ & 1.48 & 0.50 & $0.22 *$ & 0.02 & 0.14 & 0.06 & & & & & & \\
\hline 6. Age & 48.19 & 15.18 & 0.02 & 0.03 & 0.10 & -0.01 & $0.32 * *$ & & & & & \\
\hline 7. Education ${ }^{2}$ & 4.54 & 1.13 & $0.22 *$ & -0.07 & 0.02 & -0.02 & 0.06 & 0.07 & & & & \\
\hline 8. Group status ${ }^{3}$ & 1.49 & 0.50 & -0.15 & -0.07 & ${ }_{*}^{-0.20}$ & -0.23 & -0.16 & -0.17 & 0.06 & & & \\
\hline 9. Group tenure & 8.15 & 9.74 & 0.14 & 0.05 & 0.08 & 0.12 & $0.24^{* *}$ & $0.53 * *$ & 0.15 & $\begin{array}{l}-0.27 \\
*\end{array}$ & & \\
\hline 10. Group size & - & - & - & - & - & - & - & - & - & - & - & \\
\hline
\end{tabular}

Below the diagonal: personal-level data $(\mathrm{N}=125)$; above the diagonal: team-level data $(\mathrm{N}=34) .{ }^{1} 1=$ female, $2=$ male. ${ }^{2} 1=\mathrm{German}$ Hauptschulabschluss, $2=$ German Realschulabschluss, $3=$ German Abitur, $4=$ Completed apprenticeship, $5=$ university degree, $6=$ PhD degree, $7=$ Other. ${ }^{3} 1$ = paid membership, $2=$ voluntary membership, $3=$ paid and voluntary membership. ${ }^{*} p<0.05$. ${ }^{* *} p<0.01$. LMX $=$ Leader-member exchange. 
An inspection of the correlations reveals that all hypothesized predictor variables on Level 1 were significantly related to change-supporting behavior. Furthermore, these significant correlations all point in the hypothesized direction. Some control variables showed significant relationships with the study variables of interest. Educational level positively correlated with individually perceived group participation, and group status seemed to have an influence on procedural justice and change-supporting behavior.

\section{Hypotheses Testing}

Hypothesis 1 proposed that civil society group members' perceived level of group participation in governmental decision-making processes positively predicted individuals' perceived procedural justice perceptions in the Agenda 21 process. To test this hypothesis, group participation was added into the HLM equation as an individual-level predictor variable (grand-mean centered) with procedural justice as the outcome variable. No variables were entered at the group level for this analysis. As can be seen in Model 1a, participation was significantly related to procedural justice $(b=0.16, p<0.05)$. Therefore, Hypothesis 1 can be supported by the data (see Table 2).

Hypothesis 2 claimed that group members' perceived LMX quality positively predicted members' perceived procedural justice with regards to the Agenda 21 process. Analogous to Hypothesis 1, LMX was added into the regression equation as an individuallevel predictor (grand-mean centered) with procedural justice as the outcome variable (Model $1 \mathrm{~b}$ ). The analysis revealed a strong and significant positive relationship between LMX and procedural justice at the individual level $(b=0.57, p<0.001)$. This is in line with the hypothesis (see Table 2).

In Hypothesis 3, it was assumed that individually perceived procedural justice within the Agenda 21 process positively predicted change-supporting behavior towards sustainable development. Still, at the individual level of analysis, procedural justice was added into a new regression model as a Level-1 predictor with change-supporting behavior as the outcome variable (see Table 3). As can be seen in Model 2, procedural justice positively predicted change-supporting behavior in civil society group members $(b=0.74, p<0.001)$. Thus, Hypothesis 3 can also be supported.

The results of Hypothesis 3 also served as a first precondition for testing the mediation effect proposed in Hypothesis 4. Here, it was assumed that procedural justice mediated the relationship between participation and change-supporting behavior. As described in Section 1.3, the precondition was to test whether the mediating variable (procedural justice) was significantly related to the dependent variable (change-supporting behavior) after controlling for the independent variable (participation). To test this precondition, participation and procedural justice were entered into the model as individual-level predictors (grand-centered), and change-supporting behavior as the outcome variable. Model 2 in Table 3 shows that this precondition was met by the data. Comparing Model 1 with Model 2 provides further validation for the proposed mediating effect, as the beta estimate of participation drops from $\mathrm{b}=0.21(p<0.001)$ to $\mathrm{b}=0.09(p<0.05)$ with procedural justice in the equation. Lastly, the Sobel test [69] measured a significant indirect effect $(\mathrm{z}=42.16, p<0.001)$. Taken together, these results confirm Hypothesis 4.

Hypothesis 5 proposed that procedural justice mediated the relationship between LMX and change-supporting behavior. To test for this effect, the same procedure as in testing for Hypothesis 4 was applied, except that participation was excluded from the model and LMX was included (grand-mean centered). Procedural justice significantly predicted change-supporting behavior after controlling for LMX $(b=0.69, p<0.001)$. In addition, by comparing Model 1 and Model 2 in Table 4, it can be seen that the effect of LMX on change-supporting behavior decreased from $b=0.50(p<0.001)$ to $b=0.11$ (ns.) after entering procedural justice into the equation. Results of the Sobel test further suggest a significant indirect relationship $(\mathrm{z}=120.29, p<0.001)$. Thus, all requirements were met, and the hypothesis can be supported. 
Table 2. Level 1 estimates for process variables predicting procedural justice.

\begin{tabular}{|c|c|c|c|c|c|c|c|c|c|c|c|c|}
\hline & \multicolumn{3}{|c|}{ Null Model } & \multicolumn{3}{|c|}{ Model 1a } & \multicolumn{3}{|c|}{ Null Model } & \multicolumn{3}{|c|}{ Model 1b } \\
\hline & Estimate & $S E$ & $t$ & Estimate & $S E$ & $t$ & Estimate & $S E$ & $t$ & Estimate & $S E$ & $t$ \\
\hline $\begin{array}{l}\text { Intercept } \\
\text { Level } 1\end{array}$ & 5.02 & 0.08 & $60.27^{* * *}$ & 5.02 & 0.08 & $63.64^{* * *}$ & 5.02 & 0.08 & $60.27^{* * *}$ & 5.02 & 0.06 & $86.50^{* * *}$ \\
\hline Participation & & & & 0.16 & 0.07 & $2.35 *$ & & & & & & \\
\hline LMX & & & & & & & & & & 0.57 & 0.05 & $11.58^{* * *}$ \\
\hline$-2 \times \log$ & & & 314.76 & & & 309.28 & & & 314.76 & & & 236.70 \\
\hline$\Delta-2 \times \log$ & & & & & & $-5.48^{*}$ & & & & & & $-78.06^{* * *}$ \\
\hline Level 1 Var. & 0.68 & & & 0.65 & & & 0.68 & & & 0.36 & & \\
\hline Level 2 Var. & 0.04 & & & 0.03 & & & 0.04 & & & 0.02 & & \\
\hline
\end{tabular}

$N=125$ group members, $N=34$ groups. Final estimation of fixed effects with robust standard errors. ${ }^{* * *} p<0.001,{ }^{*} p<0.05$. LMX $=$ Leader-member exchange.

Table 3. Multi-level estimates for participation predicting change-supporting behavior towards more sustainability, procedural justice as a mediator.

\begin{tabular}{|c|c|c|c|c|c|c|c|c|c|c|c|c|c|c|c|}
\hline & \multicolumn{3}{|c|}{ Null Model } & \multicolumn{3}{|c|}{ Model 1} & \multicolumn{3}{|c|}{ Model 2} & \multicolumn{3}{|c|}{ Model 3} & \multicolumn{3}{|c|}{ Model 4} \\
\hline & Estimate & $S E$ & $t$ & Estimate & $S E$ & $t$ & Estimate & $S E$ & $t$ & Estimate & $S E$ & $t$ & Estimate & $S E$ & $t$ \\
\hline $\begin{array}{l}\text { Intercept } \\
\text { Level } 1\end{array}$ & 5.63 & 0.09 & $59.41^{* * *}$ & 5.63 & 0.09 & $60.01 * * *$ & 5.61 & 0.07 & $79.57^{* * *}$ & 5.61 & 0.07 & $79.28^{* * *}$ & 5.66 & 0.07 & $80.54^{* * * *}$ \\
\hline $\begin{array}{c}\text { Procedural justice } \\
\text { Level } 2\end{array}$ & & & & & & & 0.74 & 0.07 & $10.46^{* * *}$ & 0.73 & 0.09 & $7.95^{* * *}$ & 0.70 & 0.10 & $6.75^{* * *}$ \\
\hline $\begin{array}{c}\text { Procedural justice climate } \\
\text { Cross-level }\end{array}$ & & & & & & & & & & 0.06 & 0.12 & 0.53 & 0.81 & 0.07 & $11.40^{* * *}$ \\
\hline $\begin{array}{l}\text { Procedural justice climate } X \\
\text { Procedural justice }\end{array}$ & & & & & & & & & & & & & -0.22 & 0.27 & -0.79 \\
\hline$-2 \times \log$ & & & 339.25 & & & 330.32 & & & 257.68 & & & 257.54 & & & 255.29 \\
\hline$\Delta-2 \times \log$ & & & & & & $8.93^{*}$ & & & $72.64^{* * *}$ & & & 0.14 & & & 2.25 \\
\hline Level 1 Var. & 0.81 & & & 0.73 & & & 0.39 & & & 0.39 & & & 0.37 & & \\
\hline Level 2 Var. & 0.07 & & & 0.09 & & & 0.05 & & & 0.06 & & & 0.05 & & \\
\hline
\end{tabular}

$N=125$ group members, $N=34$ groups. Final estimation of fixed effects with robust standard errors. ${ }^{* * *} p<0.001{ }^{*} p<0.05$. 
Table 4. Multi-level estimates for LMX predicting change-supporting behavior towards more sustainability, procedural justice as a mediator.

\begin{tabular}{|c|c|c|c|c|c|c|c|c|c|c|c|c|c|c|c|}
\hline & \multicolumn{3}{|c|}{ Null Model } & \multicolumn{3}{|c|}{ Model 1} & \multicolumn{3}{|c|}{ Model 2} & \multicolumn{3}{|c|}{ Model 3} & \multicolumn{3}{|c|}{ Model 4} \\
\hline & Estimate & $S E$ & $t$ & Estimate & $S E$ & $t$ & Estimate & $S E$ & $t$ & Estimate & $S E$ & $t$ & Estimate & $S E$ & $t$ \\
\hline $\begin{array}{l}\text { Intercept } \\
\text { Level } 1\end{array}$ & 5.63 & 0.09 & $59.41^{* * *}$ & 5.64 & 0.08 & $72.65^{* * *}$ & 5.62 & 0.07 & $82.09^{* * *}$ & 5.62 & 0.07 & $81.36^{* * *}$ & 5.66 & 0.07 & $83.15^{* * *}$ \\
\hline LMX & & & & 0.50 & 0.08 & $5.93^{* * *}$ & 0.11 & 0.08 & 1.30 & 0.10 & 0.08 & 1.23 & 0.08 & 0.11 & 0.73 \\
\hline $\begin{array}{c}\text { Procedural justice } \\
\text { Level } 2\end{array}$ & & & & & & & 0.69 & 0.08 & $8.70^{* * *}$ & 0.68 & 0.09 & $7.53^{* * *}$ & 0.67 & 0.09 & $7.13^{* * *}$ \\
\hline $\begin{array}{c}\text { Procedural justice climate } \\
\text { Cross-level }\end{array}$ & & & & & & & & & & 0.04 & 0.12 & 0.33 & 0.83 & 0.08 & $10.56^{* * *}$ \\
\hline $\begin{array}{l}\text { Procedural justice climate } X \\
\text { Procedural justice }\end{array}$ & & & & & & & & & & & & & -0.18 & 0.25 & -0.70 \\
\hline$-2 \times \log$ & & & 339.25 & & & 296.58 & & & 258.67 & & & 258.60 & & & 261.23 \\
\hline$\Delta-2 \times \log$ & & & & & & $42.67^{* * *}$ & & & $37.91 * * *$ & & & 0.07 & & & -2.63 \\
\hline Level 1 Var. & 0.81 & & & 0.58 & & & 0.40 & & & 0.40 & & & 0.64 & & \\
\hline Level 2 Var. & 0.07 & & & 0.04 & & & 0.04 & & & 0.04 & & & 0.05 & & \\
\hline
\end{tabular}

$N=125$ group members, $N=34$ groups. Final estimation of fixed effects with robust standard errors. ${ }^{* * *} p<0.001$. LMX = Leader-member exchange. 
Hypothesis 6 claimed that group-level procedural justice climate predicted changesupporting behavior in civil society group members after controlling for individual procedural justice perceptions. In accordance with Hofmann and Gavin's [78] recommendations in testing independent effects of group-level variables, procedural justice climate was added as a group-level predictor into the equations of Hypothesis 4 and 5. Level-1 predictors (participation, LMX, and procedural justice) had been included grand-centered. In both the participation model $(b=0.06$, ns.) (Model 3, Table 3) and the LMX model $(b=0.04, n s$.) (Model 3, Table 4), procedural justice climate failed to predict change-supporting behavior after controlling for individual-level procedural justice effects. Hence, Hypothesis 6 could not be approved by the data.

In Hypothesis 7, a cross-level moderation effect of procedural justice climate affecting the relationship between individual-level procedural justice and change-supporting behavior was expected. To test this hypothesis, Hofmann and Gavin's [78] suggestions were considered. Following, in Model 4, the individual-level predictors were included group-mean centered, and cross-level influences between procedural justice and procedural justice climate were allowed. The results of testing Model 4 in Tables 3 and 4 indicated that group-level procedural justice climate did not significantly alter the individual-level relationship of procedural justice and change-supporting behavior $(b=-0.22, \mathrm{~ns} . /-0.18$, ns.). As a result, Hypothesis 7 could not be confirmed by the data.

Deriving from our analysis the resulting scheme is summarized in Figure 3.

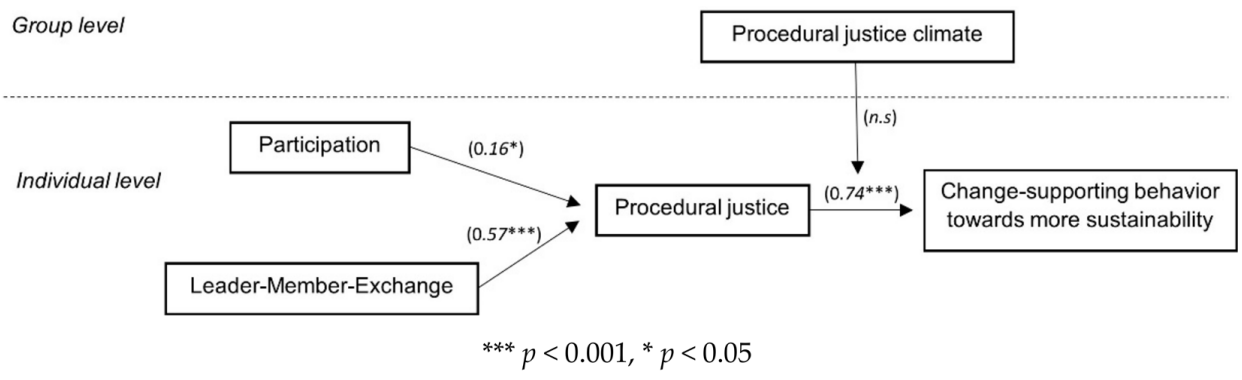

Figure 3. Resulting scheme.

\section{Discussion}

Building on social exchange theory $[7,8]$, the aim of this study was to evaluate if local Agenda 21 civil society group members who feel being involved in the local change process (i.e., participation) and experience high-quality interaction with their group leader or representative/speaker (i.e., leader-member exchange) are likely to perceive procedures within the local Agenda 21 change process as just (i.e., procedural justice). In addition, it was evaluated whether the perception of procedural justice would in turn promote change-supporting behavior in line with the goal of the local Agenda 21 to promote sustainable development in a municipality. Thereby, we broaden existing research by applying social exchange theory $[7,8]$ within a societal change context, extending the theory to this area of research.

Our findings imply that Agenda 21 activists indeed perceive the Agenda 21 process as fairer when they feel that their group has the ability to participate in the local Agenda 21 change process. This is in line with findings from organizational change management literature that reported analogous effects in the context of organizational restructuring processes $[35,36]$ and transfers them to the context of societal change.

Furthermore, we proposed that Agenda 21 activists' perceived LMX quality would predict individual procedural justice judgments. The results confirmed this hypothesis. Although studies have considered the impact of LMX in non-profit contexts, to our knowledge, we contribute to the existing research by examining the specific relationship between LMX and procedural justice in the field of civic engagement and societal change.

Next, we hypothesized that procedural justice judgments would predict civil society group members' change-supporting behavior. In line with our hypotheses, our study 
results revealed that local Agenda 21 group members showed greater change-supporting behavior towards sustainable development when they perceived the overall change process as fair. Previous studies had primarily reported effects of procedural justice on emotional and attitudinal change outcomes $[23,79]$. Therefore, the present study extends the existing research by demonstrating an effect on a subjective behavioral outcome measure in the context of societal change processes.

Next, we evaluated the mediating role of procedural justice. In line with our hypothesis, our results showed that procedural justice mediated the relationship between participation, LMX, and change-supporting behavior. These results extend Kernan and Hanges' findings [23] by indicating that the supposed mediation effect holds true not only for affective outcomes, but also for subjective behavioral outcome measures in the context of societal change. In addition, our findings expand research on LMX [43,46] by demonstrating that the relationship between LMX quality and procedural justice also maintains during change endeavors in municipalities.

Finally, the hypothesized independent effect of group-level procedural justice climate on change-supporting behavior could not be supported. Procedural justice climate unexpectedly did not predict change-supporting behavior when individual-level procedural justice was controlled for. This contradicts previous findings $[57,58]$. One explanation for this result could be the rather low ICC values of the aggregated study data. In this regard, it is likely that the low group-level reliability (ICC(2)) attenuated the assumed relationship between procedural justice climate and change-supporting behavior. Future studies should consider other types of approaches to aggregate procedural justice to create a group level measure. While the direct-consensus composition approach applied here [62] has been shown to work in previous studies $[57,63,64]$ and avoids incorporating an additional scale into the questionnaire, other approaches might be better suited concerning other diagnostic aspects.

However, this is the first study to examine procedural justice climate in local Agenda 21 groups. Potentially, activists within civil society groups are simply not more similar to each other than activists between civil society groups. One possible explanation might be the assumption that Agenda 21 activists, in general, identify more with the overall cause than with their specific group membership. This assumption, however, would need to be empirically tested, since our study is based on local Agenda 21 groups from different regional contexts which are all, however, spatially concentrated in the south of Germany. The comparison of different groups from different German cities forms the basis for first generalizations; however, it should be further expanded in terms of space and time in future studies.

In our study, we assumed a cross-level moderating effect of procedural justice climate on individual-level procedural justice which could not be supported. Here, a referent shift approach might be an appropriate measure to more thoroughly detect and disentangle individual from group perceptions. Additionally, in future research endeavors, it could be useful to take into account the effect of procedural justice climate strength (= group variability in members' justice perceptions). Previous studies have demonstrated that procedural justice climate strength moderated the relationship between procedural justice climate and individual level variables [63]. This possible effect can be explained by fairness heuristic theory $[80,81]$. Lind [80] distinguishes two phases in his theory: the judgment phase, where people form justice judgments based on collecting justice-relevant information; and the use phase, where people use their initial fairness judgments as a heuristic to determine whether to behave in a cooperative manner. Once the heuristic is in use, it is relatively stable. However, so-called phase shifting events can occur if outcomes substantially differ from what can be originally expected by applying the adopted fairness heuristic. As a result, people return to the judgment phase in order to recalibrate the applied heuristic. Fairness heuristic theory suggests that the effect of group-level justice judgments on outcome variables will be stronger as the use phase is prolonged, because this is when justice heuristics guide attitudes and behaviors. Phase-shifting events should respectively weaken 
the justice-outcome relationship. According to Colquitt et al. [63], low climate strength is an important cause of such phase-shifting events, whereas in strong climates, phase shifting is less likely to occur, and the use phase will go on uninterrupted. In this respect, one could argue, that through frequent interaction with other societal stakeholders that possess differences in interests or political views (e.g., citizens, governments, companies), civil society group members are often confronted with deviating opinions and are thus prone to elicit more phase-shifting events than typical employees within an organizational setting.

\subsection{Theoretical Implications}

In this study, social exchange theory has proven to be a framework that is suitable not only in the traditional organizational context, but also in the non-profit world. Although social exchange theory has been applied in a non-profit context before [82], the present study is the first to extend the theory to the context of societal change. Thus, researchers from the non-profit sector, or more specifically the Agenda 21 field, should be encouraged to draw and build on the findings of the present study, since they have considerable practical relevance for the incentivization of actors for local sustainability processes.

Moreover, researchers in the context of organizational change management have primarily understood change as a top-down approach. In most research articles, employees are exclusively seen as change recipients. In the present study, however, civil society group members were not only recipients of the change, but at the same time heavy drivers of the change process. This indicates that social exchange mechanisms might be of high value to analyze and predict bottom-up or even complex change initiatives. This is of high relevance as modern companies start realizing that with the ever-growing complexity of the market environment, linear, top-down approaches to organizational changes will not be sufficient to successfully adjust to the fast-paced environment in the long run [83]. Thus, as researchers we recommend adapting our research designs accordingly.

\subsection{Strengths and Limitations}

Like any study, our study has strengths and limitations. By adopting a multi-level research design, possible group-level influences of procedural justice climate have been tested and controlled for. This substantiates the reported individual-level relationships found in this study and contributes to the often-reported quest for multi-level research designs in organizational research $[84,85]$.

With regards to the study sample, civil society group members that engage in diverse fields of sustainable development (i.e., ecological sustainability, social sustainability or global justice) were incorporated. The groups are located in different regions of BadenWürttemberg, Germany, and therefore, operate in different environmental contexts (e.g., socio-economic status). Therefore, the study sample is representative of local civil Agenda 21 groups in Germany.

Concerning our measures, all scales are not only based on validated scales but were also checked for plausibility by an experienced civil society group member before the questionnaire was finalized. Consequently, satisfying internal consistencies were found in the analysis. However, we used self-ratings to assess predictors of change-supporting behavior and our dependent variables. Future research should aim to additionally include objective data such as performance indicators on the level of a municipality (social inclusion, development of $\mathrm{CO} 2$ emissions, etc.) to strengthen our research findings.

Besides these strengths, this study has some limitations that need to be addressed in order to adequately interpret the results. First, the results reported here are based on the analysis of cross-sectional data. Hence, conclusions about causality cannot be fully drawn. Second, the group sizes of the reported groups were rather small $(M=3.7)$. This, as previously mentioned, could have hurt the reliability of the group measures and possibly attenuated the cross-level relationships. Third, participation in this study was voluntary. This could have resulted in a pre-selection of study participants, selecting those who are extra committed to demonstrate extra-role behaviors, which ultimately could have 
decreased variance in the outcome variable. Fourth, although examining a behavioral outcome variable, change-supporting behavior was assessed using a subjective self-report measure, which limits the external validity of the reported study results. Lastly, it should be mentioned that although there are many parallels between traditional organizational structures and the structure of civil society, there are also some differences [3]. In this light, traditional organizations are rather isolated from the outside compared to civil society. Moreover, interactions between stakeholders in the traditional organization are more shaped by formal rules, as opposed to voluntary engagement and informal rules in civil society. One should keep these differences in mind when transferring theories from the traditional organizational context to other sorts of social systems.

\subsection{Practical Implications}

Our study results are of high practical relevance for Agenda 21 stakeholders. Members of local Agenda 21 groups are essential drivers of the change towards societal sustainability. As role models and change-promoters for citizens, it is crucial that civil society group members exert change-supporting behavior. While the majority of change activists engage voluntarily, the study findings imply that group members, nevertheless, engage in some sort of social transactions with other stakeholders of this change process. More specifically, in our study results the quality of these social transactions (i.e., participation) was positively correlated with group members' change-supporting behavior. In order to maximize local Agenda 21 group members' change-supporting behavior, local governments should, according to the present findings, actively integrate civil society groups' views into decision-making procedures within the Agenda 21 context. Practices such as round table discussions with civil society group members and stakeholders of the political sector should be promoted and scheduled on a more regular basis. However, it is not enough to give the members of local Agenda 21 groups the opportunity to take part in regular discuss with members of the local government; rather, it is crucial that their objections also have a visible influence on the decision-making processes of a city/local community. In general, local governments are advised to be mindful of local activists' opinions and actions, as every social gesture or act in favor of civil society groups could yield some sort of proactive, extra-role behavior fostering the common goal of sustainable development in return.

Furthermore, this study highlighted the importance of the role of local Agenda 21 group leaders for social exchange processes. The present findings imply that individuals who report a high-quality relationship with their group leader perceive the Agenda 21 process as fairer, and thus exert more change-supporting behavior than group members who perceive the relationship quality as rather low. Group leaders should be aware of the social influence they have on their members. Nurturing high-quality relationships with every individual should thus be a priority, as it might foster the groups' overall performance and success. Hence, group leaders are advised to have an open ear for their members concerns and doubts but also for their ideas and suggestions. However, group members play a significant part in forming high-quality LMX relationships, too. By proactively approaching their leaders when having questions, engaging in group discussions, or offering support when needed, members might draw their leaders' attention and thereby strengthen the leader-member relationship.

Overall, the present study findings imply that in complex multi-stakeholder local Agenda 21 change processes, social transactions and social exchange relationships influence stakeholders' perceptions and behaviors in the change process. In situations where interdependent agents with varying action patterns, interests, power, resources, or cultures are to cooperate, one might best accomplish personal and common goals by first and proactively assisting other agents in the process.

\subsection{Future Studies and Recommendations}

To subject our results to a generalized test, we recommend future studies. The scope of these investigations should be expanded both in terms of space (including municipalities 
from different countries), in terms of structure (including municipalities that vary according to size, economic structure, and development level), as well as in terms of time (including analyses of local Agenda 21 initiatives at different points in time of their development). In addition, these investigations should focus more on the characteristics of different Agenda 21 initiatives, also including non-supporting groups and the social and political environment of a municipality, in order to increase the generalizability of the results.

Author Contributions: Conceptualization, A.M., C.Z., M.B. and S.W.; methodology, A.M. and C.Z.; validation, A.M.; formal analysis, C.Z.; investigation, C.Z. and M.B.; resources, A.M.; data curation, C.Z. and M.B.; writing—original draft preparation, A.M., C.Z. and S.W.; writing-review and editing, A.M. and M.B.; visualization, C.Z. and M.B.; supervision, A.M. and S.W.; project administration, A.M. and S.W.; funding acquisition, A.M. and S.W. All authors have read and agreed to the published version of the manuscript.

Funding: This research was supported by a grant from the Excellence Initiative II (Field of Focus 4) of Heidelberg University.

Institutional Review Board Statement: The study was conducted according to the guidelines of the Declaration of Helsinki, and the project proposal was approved by the Excellence Initiative II (Field of Focus 4) fund of Heidelberg University (D.801000/14.052, 20.10.2014).

Informed Consent Statement: Informed consent was obtained from all subjects involved in the study.

Data Availability Statement: The data presented in this study are available on request from the corresponding author. The data are not publicly available due to privacy reasons.

Conflicts of Interest: The authors declare no conflict of interest.

\section{References}

1. Wurster, S. Staatstätigkeit II: Neue Formen politischer Steuerung. In Studienbuch Politikwissenschaft; Schmidt, M.G., Wolf, F., Wurster, S., Eds.; Springer VS: Wiesbaden, Germany, 2013; pp. 351-377.

2. OECD. DAC Guidelines and Reference Series Applying Strategic Environmental Assessment: Good Practice Guidance for Development Co-operation; OECD: Paris, France, 2006; Available online: http:/ /www.oecd.org/development/environment-development/3735 3858.pdf (accessed on 10 May 2021).

3. Wolf, H. Partizipation und Lokale Agenda 21: Ein Interkommunaler Vergleich aus Organisationssoziologischer Perspektive; Tectum Verlag: Marburg, Germany, 2005.

4. Rösler, C. Lokale Agenda 21 auf Erfolgskurs; Dokumentation des 4. Erfahrungsaustauschs; Deutsches Institut für Urbanistik: Berlin, Germany, 10-11 June 1999.

5. Geißel, B. Langer Weg zum Wandel. Lokale Agenda 21: Impulsgeber, aber kein Allerheilmittel. WZB Mitt. 2006, $114,46-47$.

6. Wurster, S.; Michel, A. Determinanten des Lokalen-Agenda-21-Erfolgs in Heidelberg. J. Self-Regul. Regul. 2020, 6, 47-68. [CrossRef]

7. Cropanzano, R.; Prehar, C.; Chen, P.Y. Using social exchange theory to distinguish procedural justice from interactional justice. Group Organ. Manag. 2002, 27, 324-351. [CrossRef]

8. Blau, P.M. Exchange and Power in Social Life; Wiley: New York, NY, USA, 1964.

9. Michel, A.; Morales-Gonzalez, M.G. Reactions to organizational change: An integrated model of health predictors, intervening variables and outcomes. In The Psychology of Organizational Change: Viewing Change from the Recipients' Perspective; Oreg, S., Michel, A., By, R.T., Eds.; Cambridge University Press: Cambridge, UK, 2013; pp. 65-91.

10. Zhao, P.; Xu, X.; Peng, Y.; Matthews, R.A. Justice, support, commitment, and time are intertwined: A social exchange perspective. J. Vocat. Behav. 2020, 120, 103432. [CrossRef]

11. Watson, E.R.; Foster-Fishman, P.G. The exchange boundary framework: Understanding the evolution of power within collaborative decision-making settings. Am. J. Community Psychol. 2013, 51, 151-163. [CrossRef] [PubMed]

12. Göll, E.; Kampfhenkel, N.; Mohrbach, E.; Nolting, K. Lokale Agenda 21-Projekte und ihre Wirkungen. Evaluation und Einschätzungen (WerkstattBericht Nr. 81); IZT_-Institut für Zukunftsstudien und Technologiebewertung: Berlin, Germany, 2007.

13. Brand, K.W.; Christ, E.; Heimerl, A.; Rau, A.; Warsewa, G. Bedingungen institutioneller Stabilisierung Lokaler Agenda-Prozesse. Modellhafte Stabilisierungspfade; Universität Bremen: München/Bremen, Germany, 2001; Available online: https: / www.yumpu. com/de/document/read/6456445/karl-werner-brand-eva-christ-angelika-heimerl-andreas-rau- (accessed on 10 May 2021).

14. Gouldner, A.W. The norm of reciprocity. Am. Sociol. Rev. 1960, 25, 547-562. [CrossRef]

15. Chaudhry, A.; Song, L.J. Rethinking psychological contracts in the context of organizational change: The moderating role of social comparison and social exchange. J. Appl. Behav. Sci. 2014, 50, 337-363. [CrossRef]

16. Kim, T.G.; Hornung, S.; Rousseau, D.M. Change-supportive employee behavior: Antecedents and the moderating role of time. J. Manag. 2011, 37, 1664-1693. [CrossRef] 
17. Neves, P.; Caetano, A. Social exchange processes in organizational change: The role of trust and control. J. Chang. Manag. 2006, 6, 351-364. [CrossRef]

18. De Haan, G.; Kuckartz, U.; Rheingans, A. Umweltkommunikation und Lokale Agenda 21; Materialien III, Paper 97-142; Forschungsgruppe Umweltbindung, Freie Universität Berlin: Berlin, Germany, 1997.

19. Cropanzano, R.; Byrne, Z.S.; Bobocel, D.R.; Rupp, D.R. Moral virtues, fairness heuristics, social entities, and other denizens of organizational justice. J. Vocat. Behav. 2001, 58, 164-209. [CrossRef]

20. Lavelle, J.; Rupp, D.E.; Brockner, J. Taking a multifoci approach to the study of justice, social exchange, and citizenship behavior: The target similarity model. J. Manag. 2007, 33, 841-866. [CrossRef]

21. Holmes, J.G. The exchange process in close relationships: Microbehavior and macromotives. In The Justice Motive in Social Behavior; Learner, M.J., Lerner, S.C., Eds.; Plenum: New York, NY, USA, 1981; pp. 261-284.

22. Konovsky, M.A.; Pugh, S.D. Citizenship behavior and social exchange. Acad. Manag. J. 1994, 37, 656-669. [CrossRef]

23. Kernan, M.C.; Hanges, P.J. Survivor reactions to reorganization: Antecedents and consequences of procedural, interpersonal, and informational justice. J. Appl. Psychol. 2002, 87, 916-928. [CrossRef] [PubMed]

24. Colquitt, J.A. On the dimensionality of organizational justice: A construct validation of a measure. J. Appl. Psychol. 2001, 86, 386-400. [CrossRef]

25. Leventhal, G.S. What should be done with equity theory? New approaches to the study of fairness in social relationships. In Social Exchange: Advances in Theory and Research; Gergen, K., Greenberg, M., Willis, R., Eds.; Plenum Press: New York, NY, USA, 1980; pp. 27-55.

26. Leventhal, G.S.; Karuza, J.; Fry, W.R. Beyond fairness: A theory of allocation preferences. In Justice and Social Interaction; Mikula, G., Ed.; Springer: New York, NY, USA, 1980; pp. 167-218.

27. Thibaut, J.; Walker, L. Procedural Justice: A Psychological Analysis; Erlbaum: Hillsdale, NJ, USA, 1975.

28. Orth, M.S. Factors Related to Resistance and Support of Organizational Change. Ph.D. Thesis, Colorado State University, Fort Collins, CO, USA, 2002.

29. Judge, T.A.; Thoresen, C.J.; Pucik, V.; Welbourne, T.M. Managerial coping with organizational change: A dispositional perspective. J. Appl. Psychol. 1999, 84, 107-122. [CrossRef]

30. Wanberg, C.R.; Banas, J.T. PredictorsEds and outcomes of openness to changes in a reorganizing workplace. J. Appl. Psychol. 2000, 85, 132-142. [CrossRef] [PubMed]

31. Michel, A.; Stegmaier, R.; Meiser, D.; Sonntag, K.H. Der Elfenbeinturm öffnet sich—Veränderungsprozesse im Hochschulbereich: Werden Commitment to Change und Person-Organisations-Passung durch Prozessmerkmale bestimmt? Z. Für Pers. 2009, 8 , 1-13. [CrossRef]

32. Molm, L.D.; Takahashi, N.; Peterson, G. In the eye of the beholder: Procedural justice in social exchange. Am. Sociol. Rev. 2003, 68, 128-153. [CrossRef]

33. Price, K.H.; Lavelle, J.J.; Henley, A.B.; Cocchiara, F.K.; Buchanan, F.R. Judging the fairness of voice-based participation across multiple and interrelated stages of decision making. Organ. Behav. Hum. Decis. Process. 2006, 99, 212-226. [CrossRef]

34. Schminke, M.; Cropanzano, R.; Rupp, D.E. Organization structure and fairness perceptions: The moderating effects of organizational level. Organ. Behav. Hum. Decis. Process. 2002, 89, 881-905. [CrossRef]

35. Paterson, J.M.; Cary, J. Organizational justice, change anxiety, and acceptance of downsizing: Preliminary tests of an AET-based model. Motiv. Emot. 2002, 26, 83-103. [CrossRef]

36. Brotheridge, C.M. The role of fairness in mediating the effects of voice and justification on stress and other outcomes in a climate of organizational change. Int. J. Stress Manag. 2003, 10, 253-268. [CrossRef]

37. Graen, G.B.; Uhl-Bien, M. Relationship-based approach to leadership: Development of the leader-member exchange (LMX) theory of leadership over 25 years. Leadersh. Q. 1995, 6, 219-247. [CrossRef]

38. Erdogan, B.; Liden, R.C. Social exchanges in the workplace: A review of recent developments and future research directions in leader-member exchange theory. In Leadership; Neider, L.L., Schriesheim, C.A., Eds.; Information Age Publishing: Greenwich, CT, USA, 2002; pp. 65-114.

39. Kamdar, D.; Van Dyne, L. The joint effects of personality and workplace social exchange relationships in predicting task performance and citizenship performance. J. Appl. Psychol. 2007, 92, 1286-1298. [CrossRef] [PubMed]

40. Liao, H.; Liu, D.; Loi, R. Looking at both sides of the social exchange coin: A social cognitive perspective on the joint effects of relationship quality and differentiation on creativity. Acad. Manag. J. 2010, 53, 1090-1109. [CrossRef]

41. Wayne, S.J.; Green, S.A. The effects of leader-member exchange on employee citizenship behavior and impression management behavior. Hum. Relat. 1993, 46, 1431-1440. [CrossRef]

42. Liden, R.C.; Sparrowe, R.T.; Wayne, S.J. Leader-member exchange theory: The past and potential for the future. Res. Pers. Hum. Resour. Manag. 1997, 15, 47-119.

43. Dulebohn, J.H.; Bommer, W.H.; Liden, R.C.; Brouer, R.L.; Liden, G.R. A meta-analysis of antecedents and consequences of leader-member exchange: Integrating the past with an eye toward the future. J. Manag. 2012, 38, 1715-1759. [CrossRef]

44. Hoye, R. Leader-member exchanges and board performance of voluntary sport organizations. Nonprofit Manag. Leadersh. 2004, 15, 55-70. [CrossRef]

45. Mueller, B.H.; Lee, J. Leader-member exchange and organizational communication satisfaction in multiple contexts. J. Bus. Commun. 2002, 32, 220-244. [CrossRef] 
46. Bhal, K.T.; Ansari, M.A. Leader-member exchange-Subordinate outcomes relationship: Role of voice and justice. Leadersh. Organ. Dev. J. 2007, 28, 20-35. [CrossRef]

47. Herscovitch, L.; Meyer, J.P. Commitment to organizational change: Extension of a three-component model. J. Appl. Psychol. 2002, 87, 474-487. [CrossRef]

48. Organ, D.W. A restatement of the satisfaction-performance hypothesis. J. Manag. 1988, 14, 547-557. [CrossRef]

49. Organ, D.W. The motivational basis of organizational citizenship behavior. In Research in Organizational Behavior; Staw, B.M., Cummings, L.L., Eds.; JAI Press: Greenwhich, CT, USA, 1990; Volume 12, pp. 43-72.

50. Chen, H.; Jin, Y.H. The effects of organizational justice on organizational citizenship behavior in the chinese context: The mediating effects of social exchange relationship. Public Pers. Manag. 2014, 43, 301-313. [CrossRef]

51. Lehmann-Willenbrock, N.; Grohmann, A.; Kauffeld, S. Promoting multifoci citizenship behavior: Time-lagged effects of procedural justice, trust, and commitment. Appl. Psychol. Int. Rev. 2013, 62, 454-485. [CrossRef]

52. Zhang, G.; Lee, G.; Zou, X. The Mediating Role of Procedural Justice between Participation in Decision-Making and Organizational Citizenship Behavior: An Empirical Study about Skeleton Government Civilian in China. Psychology 2010, 1, 300-304. [CrossRef]

53. Colquitt, J.A.; Conlon, D.E.; Wesson, M.J.; Porter, C.O.; Ng, K.Y. Justice at the millennium: A meta-analytic review of 25 years of organizational justice research. J. Appl. Psychol. 2001, 86, 425-445. [CrossRef] [PubMed]

54. Bhal, K.T. LMX-citizenship behaviour relationship: Justice as a mediator. Leadersh. Organ. Dev. J. 2006, 27, 106-117. [CrossRef]

55. Rupp, D.E.; Bashshur, M.R.; Liao, H. Justice climate past, present, and future: Models of structure and emergence. In Research in Multilevel Issues; Dansereau, F., Yammarino, F., Eds.; Elsevier: Oxford, UK, 2007; Volume 6, pp. 357-396.

56. Naumann, S.E.; Bennett, N. A case for procedural justice climate: Development and test of a multilevel model. Acad. Manag. J. 2000, 43, 881-889. [CrossRef]

57. Mossholder, K.W.; Bennett, N.; Martin, C.L. A multilevel analysis of procedural justice context. J. Organ. Behav. 1998, 19, 131-141 [CrossRef]

58. Shin, Y.; Du, J.; Choi, J.N. Multi-level longitudinal dynamics between procedural justice and interpersonal helping in organizational teams. J. Bus. Psychol. 2015, 30, 513-528. [CrossRef]

59. Kern, K. Cities as leaders in EU multilevel climate governance: Embedded upscaling of local experiments in Europe. Environ. Politics 2019, 28, 125-145. [CrossRef]

60. Schyns, B. Überprüfung einer deutschsprachigen Skala zum Leader-Member-Exchange-Ansatz = Evaluation of a german scale for the assessment of leader-member-exchange. Z. Für Differ. Und Diagn. Psychol. 2002, 23, 235-245.

61. Maier, G.; Streicher, B.; Jonas, E.; Woschée, R. Gerechtigkeitseinschätzungen in Organisationen. Die Validität einer deutschsprachigen Fassung des Fragebogens von Colquitt. Diagnostica 2007, 53, 97-108. [CrossRef]

62. Chan, D. Functional relations among constructs in the same content domain at different levels of analysis: A typology of composition models. J. Appl. Psychol. 1998, 83, 234-246. [CrossRef]

63. Colquitt, J.A.; Noe, R.A.; Jackson, C.L. Justice in teams: Antecedents and consequences of procedural justice climate. Pers. Psychol. 2002, 55, 83-109. [CrossRef]

64. Simons, T.; Roberson, Q. Why managers should care about fairness: The effects of aggregate justice perceptions on organizational outcomes. J. Appl. Psychol. 2003, 88, 432-443. [CrossRef]

65. Brislin, R.W. Back-translation for cross-culture research. J. Cross-Cult. Psychol. 1970, 1, 185-216. [CrossRef]

66. Podsakoff, P.M.; MacKenzie, S.B.; Paine, J.B.; Bachrach, D.G. Organizational citizenship behaviours: A critical review of the theoretical and empirical literature and suggestions for future research. J. Manag. 2000, 26, 513-563. [CrossRef]

67. Raudenbush, S.W.; Bryk, A.S.; Cheong, Y.F.; Congdon, R.T.; du Toit, M. HLM7: Hierarchical Linear and Nonlinear Modeling; Scientific Software International: Chicago, IL, USA, 2011.

68. Urban, D.; Mayerl, J. Regressionsanalyse: Theorie, Technik und Anwendung, 2nd ed.; VS Verlag: Wiesbaden, Germany, 2006.

69. Sobel, M.E. Asymptotic confidence intervals for indirect effects in structural equations models. In Sociological Methodology; Leinhart, S., Ed.; Jossey-Bass: San Francisco, CA, USA, 1982; pp. 290-312.

70. Hayes, A.F. A primer on multi-level modelling. Hum. Commun. Res. 2006, 32, 385-410. [CrossRef]

71. LeBreton, J.M.; Senter, J.L. Answers to 20 questions about interrater reliability and interrater agreement. Organ. Res. Methods 2008, 11, 815-852. [CrossRef]

72. Preacher, K.J.; Zhang, Z.; Zyphur, M.J. Alternative methods for assessing mediation in multilevel data: The advantages of multilevel SEM. Struct. Equ. Modeling 2011, 18, 161-182. [CrossRef]

73. James, L.R.; Demaree, R.G.; Wolf, G. Estimating within-group interrater reliability with and without response bias. J. Appl. Psychol. 1984, 69, 85-98. [CrossRef]

74. Kozlowski, S.W.J.; Hattrup, K. A disagreement about within-group agreement: Disentangling issues of consistency versus consensus. J. Appl. Psychol. 1992, 77, 161-167. [CrossRef]

75. Bliese, P.D. Within-group agreement, non-independence, and reliability: Implications for data aggregation and analysis. In Multilevel Theory, Research, and Methods in Organizations: Foundations, Extensions, and New Directions; Klein, K.J., Kozlowski, S.W.J., Eds.; Jossey-Bass: San Francisco, CA, USA, 2000; pp. 349-381.

76. Kirkman, B.L.; Chen, G.; Farh, J.; Chen, Z.X.; Lowe, K.B. Individual power distance orientation and follower reactions to transformational leaders: A cross-level, cross-cultural examination. Acad. Manag. J. 2009, 52, 744-764. [CrossRef]

77. Bliese, P.D. Group size, ICC values, and group-level correlations: A simulation. Organ. Res. Methods 1998, 1, 355-373. [CrossRef] 
78. Hofmann, D.A.; Gavin, M.B. Centering decisions in hierarchical linear models: Implications for research in organizations. J. Manag. 1998, 24, 623-641. [CrossRef]

79. Michel, A.; Stegmaier, R.; Sonntag, K.H. I scratch your back-You scratch mine. Do procedural justice and organizational identification matter for employees' cooperation during change? J. Chang. Manag. 2010, 10, 41-59. [CrossRef]

80. Lind, E.A. Fairness heuristic theory: Justice judgments as pivotal cognitions in organizational relations. In Advances in Organizational Justice; Greenberg, J., Cropanzano, R., Eds.; Stanford University Press: Stanford, CA, USA, 2001; pp. 56-88.

81. Van den Bos, K. Fairness heuristic theory: Assessing the information to which people are reacting has a pivotal role in understanding organizational justice. In Theoretical and Cultural Perspectives on Organizational Justice; Gilliland, S.W., Steiner, D.D., Skarlicki, D., Eds.; Information Age Publishing: Greenwich, CT, USA, 2001; pp. 63-84.

82. Kramer, M.W. Communication and social exchange processes in community theater groups. J. Appl. Commun. Res. 2005, 33, 159-182. [CrossRef]

83. CEB. Managing Change from the bottom up. The way organizations manage change is failing. Turn your approach upside down. Chro Q. 2016, 1, 8-10.

84. House, R.; Rousseau, D.M.; Thomas-Hunt, M. The meso paradigm: A framework for the integration of micro and macro organizational behavior. In Research in Organizational Behavior; Cummings, L.L., Staw, B.M., Eds.; JAI Press: Greenwich, CT, USA, 1995; Volume 17, pp. 71-114.

85. Torraco, R.J. Work design theory: A review and critique with implications for human resource development. Hum. Resour. Dev. Q. 2005, 16, 85-109. [CrossRef] 